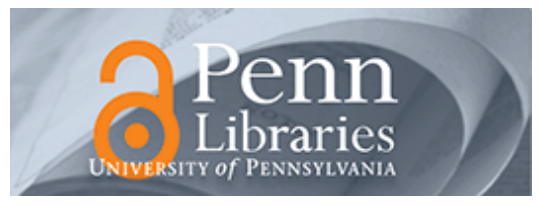

University of Pennsylvania

ScholarlyCommons

Accounting Papers

Wharton Faculty Research

9-2007

\title{
Discussion of Investor Protection and Analysts' Cash Flow Forecasts Around the World
}

Luzi Hail

University of Pennsylvania

Follow this and additional works at: https://repository.upenn.edu/accounting_papers

Part of the Accounting Commons, and the International Business Commons

\section{Recommended Citation}

Hail, L. (2007). Discussion of Investor Protection and Analysts' Cash Flow Forecasts Around the World. Review of Accounting Studies, 12 (2), 421-441. http://dx.doi.org/10.1007/s11142-007-9025-4

This paper is posted at ScholarlyCommons. https://repository.upenn.edu/accounting_papers/83

For more information, please contact repository@pobox.upenn.edu. 


\title{
Discussion of Investor Protection and Analysts' Cash Flow Forecasts Around the World
}

\begin{abstract}
DeFond and Hung [DeFond, M., \& Hung, M. (2007). Review of Accounting Studies, 12 (this issue)] test the conjecture whether financial analysts, due to demand-side pressure, compensate for the limited usefulness of reported earnings by issuing cash flow forecasts. They find that analysts supplement their earnings forecasts more frequently with cash flow forecasts in countries where antidirector rights and legal enforcement quality are poor. In my discussion, I examine their hypothesis development and empirical research design and try to extend their arguments to a time-series setting. As it turns out, the paper's main contention critically hinges on two assumptions: (1) investors' unsatisfied demand for accounting information and (2) their willingness to rely on cash flow forecasts as valuable information signals. The descriptive validity of these assumptions in an international context is a priori not obvious. I then test whether substantial changes in investor protection and/or earnings quality relate to changes in the frequency of cash flow forecasts. My analyses show that analysts' propensity to issue cash flow forecasts increases after the first prosecution under insider trading laws, after non-U.S. firms have crosslisted their shares on a U.S. exchange, or after firms have voluntarily replaced their domestic accounting standards with IFRS or U.S. GAAP. Thus, I conclude that the reasoning behind the levels results does not simply extend to a changes setting.
\end{abstract}

\section{Keywords}

international accounting, investor protection, legal system, earnings quality, analyst forecasts, cash flows

Disciplines

Accounting | International Business 


\title{
Discussion of Investor Protection and Analysts' Cash Flow Forecasts Around the World"
}

\author{
Luzi Hail \\ The Wharton School \\ University of Pennsylvania \\ 3620 Locust Walk \\ Philadelphia, PA 19104 \\ 1hail@wharton.upenn.edu
}

January 2007

\begin{abstract}
DeFond and Hung (2007) test the conjecture whether financial analysts, due to demand-side pressure, compensate for the limited usefulness of reported earnings by issuing cash flow forecasts. They find that analysts supplement their earnings forecasts more frequently with cash flow forecasts in countries where antidirector rights and legal enforcement quality are poor. In my discussion, I examine their hypothesis development and empirical research design and try to extend their arguments to a time-series setting. As it turns out, the paper's main contention critically hinges on two assumptions: (1) investors' unsatisfied demand for accounting information and (2) their willingness to rely on cash flow forecasts as valuable information signals. The descriptive validity of these assumptions in an international context is a priori not obvious. I then test whether substantial changes in investor protection and/or earnings quality relate to changes in the frequency of cash flow forecasts. My analyses show that analysts' propensity to issue cash flow forecasts increases after the first prosecution under insider trading laws, after non-U.S. firms have cross-listed their shares on a U.S. exchange, or after firms have voluntarily replaced their domestic accounting standards with IFRS or U.S. GAAP. Thus, I conclude that the reasoning behind the levels results does not simply extend to a changes setting.
\end{abstract}

Keywords: international accounting, investor protection, legal system, earnings quality, analyst forecasts, cash flows

JEL Classification: $G 15$, G18, G38, M41

\footnotetext{
* I am grateful to Holger Daske, Joseph Gerakos, Christian Leuz and the participants of the 2006 Review of Accounting Studies Conference for helpful comments and suggestions.
} 


\section{Introduction}

The interplay between countries' legal institutions and the availability of information in determining the efficiency of resource allocation and the development of financial markets is of considerable interest to regulators, standard setters and market participants. Most of prior literature has focused on the economic consequences of legal factors without explicitly addressing the role of accounting information (e.g., La Porta et al., 1997 and 1998; Beck and Levine, 2002). A few others have examined directly the link between countries' institutional settings and the properties of reported accounting numbers (e.g., Ball et al., 2000; Leuz et al., 2003; Burgstahler et al., 2006). However, relatively little evidence exists on how information intermediaries, namely financial analysts, respond to institutional forces and thus shape the flow of accounting information from firms to investors.

Adding to this stream of literature, DeFond and Hung (henceforth DH) examine whether financial analysts' propensity to provide cash flow forecasts is higher in countries in which investor protection and earnings quality are low. The basic idea is that, due to demand-side pressure, analysts compensate for the limited usefulness of reported earnings by issuing cash flow forecasts. Hence, they help investors attenuate the adverse effects of weak investor protection on the quality of corporate disclosures. To test this conjecture, DH examine a sample of more than 70,000 firm-year observations containing analyst forecast data from 36 countries over the period 1994 to 2002.

In their primary analyses, DH regress a binary variable indicating the existence of cash flow forecasts for a particular firm and year on two country-level proxies for investor protection (i.e., the antidirector rights index and the mean of three legal enforcement variables, all taken from La Porta et al., 1998). They find that analysts supplement their earnings forecasts more frequently 
with cash flow forecasts in countries where investor protection is poor. Aside from controlling for potentially correlated variables capturing a firm's accounting, operating and financing characteristics, the analysis attempts to control for self-selection bias due to the existence of analyst coverage. It further reconciles the cross-country results with earlier U.S. evidence on the association between stock returns, earnings and cash flows across firms with and without cash flow forecasts (DeFond and Hung, 2003). Moreover, the main results are robust to a series of sample selection criteria, variable definitions and estimation procedures.

Apart from being a novel description, the paper contributes to our understanding of the interplay between institutional forces and the informational role of financial analysts. Prior literature primarily focuses on the effect of institutions on analyst following and forecast accuracy. For instance, Basu et al. (1998) document that countries' accounting measurement and disclosure rules systematically affect analysts' forecast accuracy. Lang et al. (2004) show that analysts are reluctant to follow firms with incentives to withhold or manipulate information, especially when these firms are located in low investor protection countries. Furthermore, Bushman et al. (2005) provide evidence that analysts increase firm coverage upon the initial enforcement of insider trading laws, indicative of company outsiders' lower barriers to acquiring private information. DH add to this stream of literature in that they examine whether analysts respond to deficiencies in earnings quality by altering their mix of information signals. This analysis sheds light on the role of information intermediation and dissemination through financial analysts conditional on the institutional setting.

My discussion focuses on three areas: (1) hypothesis development; (2) selected research design issues; and (3) an extension of the DH arguments to a time-series setting. First, I scrutinize DH's hypothesis development. As it turns out, the paper's main conjecture critically 
hinges on two assumptions: investors' unsatisfied demand for accounting information and their willingness to rely on cash flow forecasts. Based on extant research, it is a priori not obvious whether those assumptions hold in the international setting under study. Next, I discuss selected measurement and methodological issues related to the firm-level analysis. To illustrate the sensitivity of the results to sample selection and estimation choices, I replicate DH's main findings using $\mathrm{I} / \mathrm{B} / \mathrm{E} / \mathrm{S}$ forecasts and Worldscope financial data. I find that, in a levels specification, the results are fairly robust with regard to the antidirector rights variable, although the statistical significance levels have to be interpreted with caution. More importantly, levels specifications in an international context are prone to self-selection bias and unobserved heterogeneity. To address these concerns, I attempt to extend DH's arguments to a specification in changes. Interestingly, though, comparing analysts' propensity to provide cash flow forecasts before and after substantial improvements in investor protection and/or earnings quality yield an opposite association. Analysts start issuing cash flow forecasts more frequently after the institutional or firm-level changes take place, i.e., when there is precedent that insider trading laws are strictly enforced, when firms have cross-listed on a U.S. exchange, or when they voluntarily have replaced their domestic accounting standards with International Financial Reporting Standards (IFRS) or U.S. GAAP. My findings cast doubt on the validity of DH's arguments and offer opportunities for future research.

\section{The Informational Role of Financial Analysts in an International Setting}

DH develop their hypotheses based on the role of disclosure in modern capital markets (see, e.g., Healy and Palepu, 2001). In this framework, intermediaries like financial analysts facilitate the flow of information between corporate managers and investors. By increasing the credibility of corporate disclosures and uncovering new information, analysts mitigate information and 
incentive problems that impede efficient resource allocation. But in a cross-country setting, we additionally have to consider countries' legal and institutional forces when modeling the interaction between business enterprises, investors and analysts. That is, we must examine how managers, financial analysts and investors utilize accounting information to resolve information asymmetries and communicate with each other conditional on a firm's legal and institutional environment (e.g., Watts and Zimmerman, 1986; Ball, 2001).

With this in mind, I turn to DH's hypothesis development, which evolves from two main premises: first, institutions to protect outside investors determine the usefulness of reported earnings, and second, the usefulness of reported earnings — and thus, indirectly, outside investor protection-determines the type of information analysts provide, for example, their propensity to issue cash flow forecasts. The first link is drawn from prior literature. Evidence in studies like Ball et al. (2000), Guenther and Young (2000), or Leuz et al. (2003) suggests that weak investor protection institutions provide managers with incentives to report earnings of lower quality. The second link directly builds on these findings. DH argue that when the usefulness of reported earnings is low, market participants likely turn to other information sources. Financial analysts, responding to such a demand-side pressure, then start supplementing earnings forecasts with cash flow forecasts.

The above line of argument hinges on two implied assumptions: in weak investor protection (i.e., low earnings quality) countries, (1) analysts readily respond to investors' unsatisfied demand for additional accounting information and (2) their cash flow forecasts represent a valuable input to investors' decision-making. Since these assumptions are crucial for the DH study, I will next assess their descriptive validity in more detail. 


\subsection{Do Investors in Weak Investor Protection Countries Demand Additional Accounting}

\section{Information?}

The first assumption implies that the flow of accounting information between managers and outside investors is not in equilibrium, but investors likely demand more information that managers - for whatever reason-are not willing to supply. The motives for this imbalance, though, remain vague for at least three reasons. First, it is not clear whether such a demand-side overhang in the market for corporate information exists. The point of the proposition in Ball (2001) and others is that the demand for accounting information is a function of countries' economic, legal and political infrastructures. The mere fact that accounting numbers are less useful to investors does not indicate inefficient contracting with corporate managers but may just represent the optimal response to the infrastructure already in place. For instance, firms in countries with weak investor protection have more concentrated ownership (La Porta et al., 1999), rely more heavily on debt financing from banks or the state (Beck and Levine, 2002), and are subject to reduced pressure from capital markets (Burgstahler et al., 2006). Thus, the lower usefulness of reported earnings simply marks managers' adequate response to less demand for high quality accounting information because they have other ways to efficiently communicate with corporate outsiders (e.g., Leuz and Wüstemann, 2004).

Second, although insiders' private control benefits potentially offer a rationale for investors' unsatisfied demand for accounting information, it is not clear why this motive should apply to a setting where investors' uncertainty ultimately resolves. Incentives to conceal the extortion of private control benefits only apply as long as managers are reasonably assured that their private information will not leak to outside investors (e.g., Shleifer and Vishny, 1997; Bushman and Smith, 2001). Whenever the private control benefits are detected, though, outside investors will 
likely take disciplinary action. Assuming that corporate disclosures and analyst forecasts serve as substitutes, the source of information does not matter in preventing managers from extracting private control benefits. Hence, managers should be fully aware that the results of their actions - even though not communicated through reported earnings - will end up in the public domain via analysts' cash flow forecasts. The question then becomes why managers choose to rely on intermediaries instead of disclosing information on their own.

Third, it is not obvious what motivates financial analysts to promptly satisfy investors' demand for accounting information. Evidence in Chang et al. (2000) and Lang et al. (2004) suggests that, as a consequence of lower analyst following in weak investor protection countries, competition among analysts is limited. In addition, capital markets in those countries are less developed (La Porta et al., 1997), even further reducing the informational role of analysts. Thus, it may well be that analysts—relieved from the pressure to produce highly accurate forecasts in the short-run - provide a fuller but less precise set of information (i.e., cash flow forecasts) to facilitate long-term decision-making. This may, in turn, favor the use of alternate valuation models (see, e.g., Penman and Sougiannis, 1998; Francis et al., 2000). Finally, since providing cash flow forecasts consumes costly analyst time and effort, its cost should be offset by benefits. But again, given the lower importance of capital markets in weak investor protection countries, the sources of those alleged benefits remain vague.

\subsection{Do Investors in Weak Investor Protection Countries Care about Cash Flow Forecasts?}

The second implied assumption is that investors in countries with lower quality reported earnings place more weight on cash flow forecasts. This leads to empirically testable predictions about how investors perceive reported and forecasted earnings and cash flows conditional on 
countries' investor protection institutions. However, extant evidence suggests a lower reliance on earnings and cash flows in weak investor protection countries.

First, compared with earnings, cash flows are harder to predict, more volatile and suffer from timing problems (e.g., Dechow, 1994; Subramanyam, 1996). Thus, cash flow forecasts tend to be a noisy measure of true firm performance. ${ }^{1}$ Second, prior literature suggests that earnings are less value relevant in weak investor protection countries (e.g., Ali and Hwang, 2000; Hung, 2001). Consistent with this evidence, DH find that the association between changes in earnings and long-run stock returns is significantly higher when investor protection is strong (see their Table 3, Panel B). Investors should therefore pay less attention to earnings when they are of low quality. However-somewhat opposite to the argument in DH but in line with, e.g., Bartov et al. (2001) — there is no evidence of a substitution effect between the value relevance of earnings and cash flows. In the same table, DH report that changes in actual cash flows are not related to stock returns, regardless of a country's investor protection institutions. This finding contradicts the notion that market participants likely put more weight on cash flow data whenever earnings are less informative.

\section{Research Design Issues and Implications}

My methodological comments focus on two points: (1) sample and database selection and (2) the explanation of country-level factors using firm-level regressions. ${ }^{2}$ The first issue relates to how the input data sources and the sample selection criteria may affect one of the study's main empirical proxies, namely the number of firms having analyst cash flow forecasts. DH collect

\footnotetext{
${ }^{1}$ This problem seems even more pervasive in countries with weak investor protection institutions. According to an earlier draft of the paper, DH examine the properties of analyst forecasts across countries with weak and strong investor protection and document that average cash flow forecast errors and dispersion are significantly larger under weak investor protection regimes (over and above of being larger than earnings forecast errors and dispersion).

${ }^{2}$ I hasten to add that DH subject their main findings to a battery of robustness tests addressing many of the methodological concerns raised during the RAST conference. I therefore consider my comments in Section 3 as emphasizing some critical research design issues rather than as criticism of DH's empirical approach.
} 
their sample from the intersection of the $\mathrm{I} / \mathrm{B} / \mathrm{E} / \mathrm{S}$ database and Compustat Global and include observations with the necessary country-specific and firm-level control variables. However, one could construct the sample differently. To illustrate the point, I compare DH's proportions of firms having one-year ahead analyst earnings forecasts and at least one cash flow forecast by country (see column 1 of Table 1) to four alternate sampling procedures. In column 2 the proportions are computed solely based on $\mathrm{I} / \mathrm{B} / \mathrm{E} / \mathrm{S}$ data, leading to a substantial decline in most of the percentages (e.g., for Argentina the proportion of firms with cash flow forecasts drops from $80 \%$ to $53 \%$ ). Next, I apply the same sampling criteria as DH but collect financial data from the Worldscope database instead of Compustat Global. This produces very similar percentages, with two notable exceptions. For Japan and the U.S., the proportions of firms with cash flow forecasts increase from $14 \%$ to $25 \%$ and $32 \%$, respectively. ${ }^{3}$ The values increase even further once I limit the sample to the 300 largest firm-years by country, measured by US\$ market value of outstanding equity at the end of the fiscal year (column 4). Finally, I compute the percentages based on 100 randomly selected observations by country and report them in the last column of Table 1. Taken together, the proportions of firms with cash flow forecasts are quite sensitive to data requirements and input databases, thereby underscoring DH's attempt to control for selfselection bias. On the other hand, all the samples are highly correlated with rank correlations of 0.64 or more between DH's values and the four alternative sampling procedures (see the last row of Table 1).

The second methodological issue relates to the estimation procedure. DH attempt to link analyst forecast behavior to the variation in country-level investor protection using firm-level regressions. Thus, they face a trade-off between incorporating firm-specific factors into the

\footnotetext{
${ }^{3}$ This increase is mainly due to smaller firm coverage by Worldscope in those two countries. Generally, firm coverage by country in Worldscope is larger than in Compustat Global. See also footnote 4.
} 
regressions while at the same time adequately addressing the dramatic loss in degrees of freedom for their investor protection variables, and the lack of power when estimating a country-level model. To illustrate the point, I estimate firm-level and country-level models and report the results in Table 2. I start with replicating DH's main findings employing the following firmlevel Logit regression specification:

$$
\begin{aligned}
\text { Cash Flow Forecast Indicator } & { }_{i, t}=\beta_{0}+\beta_{1} \text { ANTIDIR }_{c}+\beta_{2} \text { ENFOR }_{c}+\beta_{3} \text { DISCLOSE }_{c} \\
& +\beta_{4} \text { FRGINV }_{c}+\beta_{5} \text { BIG }_{i}+\beta_{6} \text { ANALYST }_{i, t}+\beta_{7} \text { SIZE }_{i, t}+\beta_{8} \text { XLIST }_{i} \\
& +\sum \beta_{j} \text { Industry Fixed Effects }_{i}+\sum \beta_{k} \text { Year Fixed Effects }_{t}+\varepsilon_{i, t},
\end{aligned}
$$

where $i, t$ and $c$ represent firm, year and country indicators. The dependent variable is a binary indicator set to one if the firm has both earnings and cash flow forecasts in a particular year and zero if it only has earnings forecasts. The main variables of interest are the antidirector rights index (ANTIDIR) and the mean of three enforcement variables (ENFOR, i.e., efficiency of the judicial system, rule of law, and corruption index), all taken from La Porta et al. (1998). According to DH, I include the following controls: DISCLOSE reflects a country's disclosure practice using the country means of the 1995 CIFAR firm-level disclosure scores. FRGINV equals the average foreign investments in an economy scaled by GDP (see DH, Table 2). BIG5 is a binary variable indicating the existence of a Big Five audit firm. ANALYST is the number of analysts issuing forecasts for the firm in a given year. SIZE is the natural log of the market value of outstanding equity (in US\$ thousands) at the end of the year. XLIST stands for a binary indicator taking on the value of one if the company's shares are listed on multiple international exchanges. In addition, the regressions include industry and year-fixed effects. 
The first column in Table 2 confirms DH's main results using Worldscope financial data. ${ }^{4}$ Yet the question becomes whether in the firm-level panel data set the standard errors properly reflect the correlations in the residuals across observations and time, especially in case of the country-level variables (see, e.g., Petersen, 2006; Thompson, 2006). DH prefer standard errors clustered by country and industry. For comparison, I also report results using country clusters (model 2 in Table 2). The choice between the two approaches is not obvious, and depends on the number of clusters and observations per cluster among other things. On the one hand, in many countries, the number of firms classified by two-digit SIC code will be very small; on the other hand, we only have 36 sample countries. Furthermore, the structure of the serial and crosssectional dependence may be more complex than under either clustering assumption. Note, however, that in both cases the investor protection variables are negative and highly significant, albeit with substantially smaller z-statistics when clustering by country. In the remainder of Table 2, I present results from country-level OLS regressions using the following reduced form model:

\section{Cash Flow Forecast Proportion ${ }_{c}=\beta_{0}+\beta_{1}$ ANTIDIR $_{c}+\beta_{2}$ ENFOR $_{c}+\beta_{3}$ DISCLOSE $_{c}$}

$$
+\beta_{4} \mathrm{FRGINV}_{c}+\varepsilon_{c} \text {. }
$$

The dependent variable is the proportion of firms with cash flow forecasts by country. ${ }^{5}$ All other variables and the samples are as previously described. This approach resolves the dependency in the residuals problem but drastically reduces the number of observations. As a result only ANTIDIR remains negative and statistically significant at conventional levels. The model further assumes homogenous within-country associations, although firm-specific

\footnotetext{
${ }^{4}$ See model 2 in DH's Table 4. The opposite signs on the SIZE and XLIST coefficients are likely due to differing sample compositions and variable definitions. First, the Worldscope sample only contains 7,753 Japanese and 4,234 U.S. firm-years (compared to 16,645 and 21,728, respectively, in DH). Second, while XLIST reflects all international cross-listings, DH only consider cross-listings on a U.S. exchange.

${ }^{5}$ To ensure that the predicted values from the OLS regressions fall between zero and one, I apply the following log transformation to the percentage values: $\ln (x /(1-x))$ where $x$ is the raw value.
} 
characteristics arguably affect analysts' propensity to forecast cash flows (DeFond and Hung, 2003). Alternatively, one could extract country-fixed effects based on firm-level OLS regressions and then regress those country-fixed effects on the investor protection variables (see Hail and Leuz, 2006a, for an example). While this approach again collapses the sample to 36 observations assigning each country equal weight, it exploits firm-level information and controls for differences in within-country economic heterogeneity. In summary, it is a complex task to assess the statistical significance of the investor protection variables, suggesting that one has to interpret the z-statistics presented in $\mathrm{DH}$ with caution.

\section{Do the Results Extend to a Specification in Changes? A Robustness Test}

In this section, I conduct a robustness test of the argument in DH that financial analysts compensate for the limited usefulness of reported earnings by issuing cash flow forecasts. DH examine their conjecture by relating the level of investor protection and/or earnings quality to analysts' propensity to issue cash flow forecasts. ${ }^{6}$ The same argument should apply to a specification in changes, i.e., changes in investor protection institutions and/or earnings quality should lead to changes in the frequency of cash flow forecasts. Moreover, the use of a panel data set helps mitigate concerns about self-selection bias and correlated omitted variables as each firm serves as its own control, thereby increasing our confidence in a causal relation between the two primary constructs of interest. To empirically test the changes analysis, I identify three crosscountry settings indicating a substantial increase in investor protection and/or earnings quality over time: (1) the initial enforcement of insider trading laws for national stock markets; (2) the

\footnotetext{
${ }^{6}$ In the final draft of the paper, DH introduce a changes analysis into the robustness tests' section using their I/B/E/S-Compustat Global database and replicating two of the three settings outlined in Section 4 below. Their findings generally confirm the results of my changes tests, although their post-change indicator variable becomes insignificant once they include year fixed effects (see also footnote 12). In any event, neither their nor my attempts provide evidence of a significantly negative association between changes in investor protection and analysts' propensity to issue cash flow forecasts.
} 
cross-listing of non-U.S. firms on a U.S. exchange; and (3) firms' voluntary adoption of IFRS or U.S. GAAP accounting standards. ${ }^{7}$

The first setting identifies one of the rare instances where we can actually observe a change in country-level institutions. According to Bhattacharya and Daouk (2002), it is the initial enforcement (not the enactment) of insider trading laws that markedly improves the efficiency of capital markets as measured by a decrease in cost of equity capital. In a similar vein, Bushman et al. (2005) document an increase in the intensity and breadth of analyst coverage after the first enforcement of insider trading laws. Hence, for my time-series analyses, I define INSIDETR as a binary indicator taking on the value of one beginning in the year of the first prosecution under insider trading laws.

The second setting focuses on a set of non-U.S. firms that choose to cross list on a U.S. exchange. According to the bonding argument (e.g., Coffee, 1999; Stulz, 1999; Doidge et al., 2004), a U.S. exchange listing strengthens outside investor protection via exposure to SEC enforcement and the threat of shareholder litigation and, consequently, reduces the agency costs of controlling shareholders. Moreover, listings on NASDAQ, NYSE or AMEX typically imply substantial changes in firms' information environment indicating an increase in accounting quality (Lang et al., 2003a and 2003b), which ultimately could manifest in a lower cost of capital (Hail and Leuz, 2006b). For my changes analysis, I set ADR, a binary indicator, equal to one beginning in the year of non-U.S. firms' exchange listing in the U.S. ${ }^{8,9}$

\footnotetext{
${ }^{7}$ The International Accounting Standards (IAS) were the standards issued by the International Accounting Standards Committee (IASC), which was succeeded by the International Accounting Standards Board (IASB) to issue the International Financial Reporting Standards (IFRS). For ease of exposition, I refer to both accounting regimes using the term IFRS.

${ }^{8}$ See Hail and Leuz (2006b) for a detailed description of the ADR panel construction.

${ }^{9}$ Note that the cross-listing sample also includes 473 observations from Canadian firms. Strictly speaking, these are not ADR firms since they can directly list their shares (rather than depositary receipts) in the U.S., and are exempted from certain U.S. reporting requirements under the Multi-Jurisdictional Disclosure System. However, the results of
} 
The third setting considers a group of firms that voluntarily switches from reporting under domestic accounting standards to either IFRS or U.S. GAAP. Such a switch represents a substantial increase in a firm's commitment to disclosure, which not only affects the properties of reported earnings (Barth et al., 2005) and the perceptions of their quality by market participants (Daske and Gebhardt, 2006) but may also lower costs of capital that arise from information asymmetries (Leuz and Verrecchia, 2000). Based on the classification in Worldscope, I define IFRS as a binary indicator that equals one beginning in the year of firms' voluntary adoption of IFRS or U.S. GAAP. ${ }^{10}$

For each setting, I construct a panel comprising all firm-year observations over the period 1994 through 2004, for which I/B/E/S one-year ahead forecasts and Worldscope financial data to compute the control variables exist. To ensure that sample firms are subjected to the institutional change, I only include firms with at least one yearly observation in the period before and after the change in investor protection or earnings quality. Adopting DH's arguments for the changes analysis, I expect that analysts' propensity to issue cash flow forecasts decreases once reported earnings have become more useful. Investors-adapting to the more informative earnings numbers - should reduce their demand for supplementing cash flow information. Analysts, in turn, should react to the decrease in demand-side pressure by cutting back their costly cash flow forecasting efforts. Thus, I predict a negative relation between the change in investor protection and/or earnings quality and the change in the frequency of analysts' cash flow forecasts.

Table 3 presents univariate results of the changes analysis. For each setting, I compute the proportion of firms having cash flow forecasts before and after the change. I further split the

\footnotetext{
the subsequent analyses do not depend on the inclusion of these firms, and if anything get stronger when I exclude Canadian firms from the tests.

${ }^{10}$ Since Worldscope's classification of accounting standards is fairly ambiguous, I manually cross-check in order to assure that sample firms truly switched to either IFRS or U.S. GAAP. This limits the sample to observations from Austria, Belgium, Denmark, Finland, Germany, Hong Kong, South Africa, Switzerland and Turkey.
} 
samples into low and high investor protection countries according to the median value of ANTIDIR. In Panel A, I use INSIDETR to partition the time-series of observations. The sample comprises 6,096 firm-years from 12 countries representing 921 unique firms. Contrary to expectations, the pre-period in low investor protection countries exhibits the lowest cash flow forecasts' percentage (37\%). Analysts in those countries not only issue significantly fewer cash flow forecasts compared with strong investor protection countries (58\%) but also start issuing significantly more cash flow forecasts once the first prosecution under insider trading laws takes place (75\%). A similar, albeit slightly weaker, pattern appears when using ADR (Panel B) or IFRS (Panel C) to partition the time-series of observations. The sample of cross-listing firms consists of 1,151 firm-years from 19 countries and 137 unique firms, while the IFRS or U.S. GAAP sample comprises 101 firms from nine countries totaling 735 firm-years. Regardless of the ANTIDIR status, the proportion of analysts' cash flow forecasts is always significantly higher in the post-period even though reported earnings presumably have become more useful to investors. Overall, the results suggest that, instead of reducing their efforts, analysts augment the supply of information after substantial improvements in investor protection and earnings quality.

Since the univariate comparisons do not control for differences in firm characteristics associated with analysts' forecast propensity, I next employ regression analysis. To analyze the effects of intertemporal changes in investor protection and/or earnings quality, I estimate the following firm-level Logit regression model:

Cash Flow Forecast Indicator ${ }_{i, t}=\alpha_{1}$ Post-Change in Investor Protection/Earnings Quality Indicator $_{i, t}+\alpha_{2} \mathrm{ANALYST}_{i, t}+\alpha_{3} \mathrm{SIZE}_{i, t}+\alpha_{4} \mathrm{LEV}_{i, t}+\alpha_{5} \mathrm{FRGSALES}_{i, t}+\alpha_{6} \mathrm{ROE}_{i, t}$ $+\sum \alpha_{j}$ Firm Fixed Effects $_{i}+\sum \alpha_{k}$ Year Fixed Effects ${ }_{t}+v_{i, t}$,

where $i$ and $t$ represent firm and year indicators. The dependent variable is the same as in equation (1). To exploit the panel structure of the data, I include firm fixed effects in the 
regressions. This not only accounts for time-invariant firm (as well as country and industry) characteristics that are unobservable and difficult to measure, it also lets me interpret $\alpha_{1}$ as the incremental effect compared to the pre-period. Depending on the model specification, I include three sets of control variables. First, in accordance with DH, I include ANALYST and SIZE, measured as previously described. ${ }^{11}$ Second, I add year fixed effects to filter out general trends in analysts' propensity to forecast cash flows. In this case, we can interpret $\alpha_{1}$ as the marginal effect of the institutional change over and above any unobserved (constant) firm and year characteristics. ${ }^{12}$ Third, I include three additional firm-level controls that may be related to the dependent variable. Financial leverage (LEV), computed as the ratio of total liabilities to market value of outstanding equity, captures cash flows' relative superiority in valuing firms with poor financial health (DeFond and Hung, 2003). Foreign sales as percent of total sales (FRGSALES) account for firms' exposure to foreign markets and investors, which likely indicates greater information asymmetries. ${ }^{13}$ Finally, accounting return on equity (ROE) is earnings per share divided by beginning of period book value and stands for the ambiguous relation between corporate disclosure policy and firm performance (e.g., Lang and Lundholm, 1993).

Table 4 reports coefficient estimates and, in parentheses, z-statistics based on robust standard errors across the three changes samples. ${ }^{14}$ Regardless of which partitioning variable or model specification I choose, the coefficients on the post-change indicators are always positive and

\footnotetext{
${ }^{11}$ Compared with the original DH specification in their Table 4, the country-level variables for antidirector rights, law enforcement, disclosure and foreign investment cancel out in the firm fixed effects regression. The same holds for the firm-level measures of audit quality and multiple listings because they are only available for the most recent fiscal year in the Worldscope database and therefore are time-invariant.

${ }^{12}$ The introduction of year fixed effects is problematic insofar as the effect I am trying to measure may be correlated with the general trend in the data and hence the yearly constants absorb a portion of the effect. I therefore consider these specifications as a rather conservative estimate of the change effect.

${ }^{13}$ To limit sample attrition, I set FRGSALES equal to zero for observations with missing foreign sales data in Worldscope. Unreported analyses confirm that the results do not hinge on this assumption.

${ }^{14}$ In additional analyses, I estimate firm fixed effects regressions using OLS and the log transformed-i.e., $\ln (x /(1$ $x$ )) where $x$ is the raw value - proportion of the number of cash flow forecasts by firm as the dependent variable. Results (not tabulated) are very similar to those reported in the text, and none of the inferences change.
} 
significant at the $5 \%$ level or better (two-tailed). The magnitude of the coefficient estimates is largest in Model 1, i.e., before accounting for a general trend in the data. Closer inspection of the year fixed effects reveals that all coefficients are positive and highly significant, suggesting that analysts' propensity to issue cash flow forecasts increases over the years. Nonetheless, the marginal effects of INSIDETR, ADR and IFRS remain significantly positive after controlling for the time-series trend and the inclusion of additional firm-level controls. ${ }^{15}$

Taken together, the regression results strongly confirm the univariate findings. The evidence is consistent with financial analysts issuing cash flow forecasts more frequently after the first prosecution under insider trading laws in a country and after firms have cross-listed on a U.S. exchange or voluntarily switched to IFRS or U.S. GAAP. Thus, my changes analyses yield opposite associations to the conjecture in $\mathrm{DH}$, thereby casting doubt on the interpretation of their findings in the levels tests.

\section{Conclusions}

DH provide evidence consistent with the conjecture that financial analysts, due to demandside pressure, compensate for the limited usefulness of reported earnings by issuing cash flow forecasts. In my discussion, I point out that DH's main contention critically hinges on two assumptions whose descriptive validity in an international context is far from obvious. First, it is not clear whether, in weak investor protection countries, investors actually demand additional accounting information and, if so, what motivates financial analysts to undertake costly efforts to satisfy this demand. Second, it remains an open question whether cash flow information

\footnotetext{
${ }^{15}$ Consistent with Bushman et al. (2005), the significantly positive coefficient on ANALYST throughout the changes analyses suggests that analyst coverage increases after substantial improvements in investor protection and earnings quality.
} 
represents useful input to investors' valuation models, especially in an environment where outside investor protection is weak and reported earnings numbers are of low quality.

To better assess the validity of DH's arguments, I attempt to extend their levels analysis to a specification in changes, i.e., I empirically test whether substantial changes in investor protection and/or earnings quality relate to changes in the frequency of cash flow forecasts. The changes approach not only helps mitigate concerns about self-selection bias and unobserved heterogeneity but also increases our confidence in a causal relation between the two theoretical constructs. Interestingly, though, my univariate and regression tests yield an association opposite what DH's levels analysis would predict. Analysts supplement their earnings forecasts more frequently with cash flow forecasts after a country's first prosecution under insider trading laws and after non-U.S. firms have cross-listed their shares on a U.S. exchange or voluntarily adopted IFRS or U.S. GAAP. Thus, my analyses cast doubt on the purported reasons for the association in the levels specification.

The apparent failure to reconcile the two approaches offers ample opportunities for future research. Cross-sectional differences in analyst evaluation and compensation, the information investors base their valuations on, or the role of capital market benchmarks and pressures on firm management are just a few examples that could help explain why analysts' information supply differs across countries and over time. DH take an important step in that direction. Yet, more evidence is needed to better understand how the institutional setting affects the informational role of financial analysts in an international context. 


\section{References}

Ali, A. and L.-S. Hwang. (2000). "Country-Specific Factors Related to Financial Reporting and the Value Relevance of Accounting Data." Journal of Accounting Research 38, 1-21.

Ball, R. (2001). "Infrastructure Requirements for an Economically Efficient System of Public Financial Reporting and Disclosure.” In Litan, R. and R. Herring (eds.), Brookings-Wharton Papers on Financial Services. Washington DC: Brookings Institution Press, 127-169.

Ball, R., S. P. Kothari and A. Robin. (2000). "The Effect of International Institutional Factors on Properties of Accounting Earnings." Journal of Accounting and Economics 29, 1-51.

Barth, M., W. Landsman and M. Lang. (2005). "International Accounting Standards and Accounting Quality." Working paper, Stanford University and University of North Carolina.

Bartov, E., S. Goldberg and M.-S. Kim. (2001). "The Valuation-Relevance of Earnings and Cash Flows: An International Perspective.” Journal of International Financial Management and Accounting 12, 103-132.

Basu, S., L. Hwang and C.-L. Jan. (1998). "International Variation in Accounting Measurement Rules and Analysts' Earnings Forecast Errors." Journal of Business Finance \& Accounting 25, 1207-1247.

Beck, T. and R. Levine. (2002). "Industry Growth and Capital Allocation: Does Having a Market- or Bank-Based System Matter?” Journal of Financial Economics 64, 147-180.

Bhattacharya, U. and H. Daouk. (2002). "The World Price of Insider Trading." Journal of Finance 57, 75-108.

Burgstahler, D., L. Hail and C. Leuz. (2006). “The Importance of Reporting Incentives: Earnings Management in European Private and Public Firms." The Accounting Review 81, 983-1016.

Bushman, R., J. Piotroski and A. Smith. (2005). "Insider Trading Restrictions and Analysts' Incentives to Follow Firms." Journal of Finance 60, 35-66.

Bushman, R. and A. Smith. (2001). "Financial Accounting Information and Corporate Governance." Journal of Accounting and Economics 32, 237-333.

Chang, J., T. Khanna and K. Palepu. (2000). "Analyst Activity around the World." Working paper, University of Pennsylvania and Harvard University.

Coffee, J. (1999). "The Future as History: The Prospects for Global Convergence in Corporate Governance and its Implications." Northwestern University Law Review 93, 641-707.

Daske, H. and G. Gebhardt. (2006). "International Financial Reporting Standards and Experts' Perceptions of Disclosure Quality." Abacus 42, 461-498.

Dechow, P. (1994). "Accounting Earnings and Cash Flows as Measures of Firm Performance: The Role of Accounting Accruals." Journal of Accounting and Economics 18, 3-42.

DeFond, M. and M. Hung. (2003). “An Empirical Analysis of Analysts' Cash Flow Forecasts." Journal of Accounting and Economics 35, 73-100.

DeFond, M. and M. Hung. (2007). "Investor Protection and Analysts' Cash Flow Forecasts Around the World." Review of Accounting Studies 12, this issue.

Doidge, C., G. Karolyi and R. Stulz. (2004). "Why Are Foreign Firms Listed in the U.S. Worth More?” Journal of Financial Economics 71, 205-238. 
Francis, J., P. Olsson and D. Oswald. (2000). "Comparing the Accuracy and Explainability of Dividend, Free Cash Flow, and Abnormal Earnings Equity Value Estimates." Journal of Accounting Research 38, 45-70.

Guenther, D. and D. Young. (2000). "The Association between Financial Accounting Measures and Real Economic Activity: A Multinational Study." Journal of Accounting and Economics $29,53-72$.

Hail, L. and C. Leuz. (2006a). "International Differences in the Cost of Equity Capital: Do Legal Institutions and Securities Regulation Matter?" Journal of Accounting Research 44, 485531.

Hail, L. and C. Leuz. (2006b). "Cost of Capital Effects and Changes in Growth Expectations around U.S. Cross-Listings." Working paper, University of Pennsylvania and University of Chicago.

Healy, P. and K. Palepu. (2001). "Information Asymmetry, Corporate Disclosure, and the Capital Markets: A Review of the Empirical Disclosure Literature." Journal of Accounting and Economics 31, 405-440.

Hung, M. (2001). "Accounting Standards and Value Relevance of Financial Statements: An International Analysis." Journal of Accounting and Economics 30, 401-420.

Lang, M., K. Lins and D. Miller. (2003a). “ADRs, Analysts, and Accuracy: Does Cross Listing in the United States Improve a Firm's Information Environment and Increase Market Value?" Journal of Accounting Research 41, 317-345.

Lang, M., K. Lins and D. Miller. (2004). "Concentrated Control, Analyst Following, and Valuation: Do Analysts Matter Most When Investors Are Protected Least?” Journal of Accounting Research 42, 589-623.

Lang, M. and R. Lundholm. (1993). "Cross-Sectional Determinants of Analyst Ratings of Corporate Disclosures.” Journal of Accounting Research 31, 246-271.

Lang, M., J. Smith Raedy and M. Higgins Yetman. (2003b). "How Representative Are Firms That Are Cross-Listed in the United States? An Analysis of Accounting Quality." Journal of Accounting Research 41, 363-386.

La Porta, R., F. Lopez-de-Silanes and A. Shleifer. (1999). "Corporate Ownership around the World." Journal of Finance 54, 471-517.

La Porta, R., F. Lopez-de-Silanes, A. Shleifer and R. Vishny. (1997). "Legal Determinants of External Finance." Journal of Finance 52, 1131-1150.

La Porta, R., F. Lopez-de-Silanes, A. Shleifer and R. Vishny. (1998). "Law and Finance." Journal of Political Economy 106, 1113-1155.

Leuz, C., D. Nanda and P. Wysocki. (2003). "Earnings Management and Investor Protection: An International Comparison.” Journal of Financial Economics 69, 505-527.

Leuz, C. and R. Verrecchia. (2000). "The Economic Consequences of Increased Disclosure." Journal of Accounting Research 38, 91-124.

Leuz, C. and J. Wüstemann. (2004). "The Role of Accounting in the German Financial System." In Krahnen, J. and R. Schmidt (eds.), The German Financial System. Oxford: Oxford University Press, 450-482.

Penman, S. and T. Sougiannis. (1998). "A Comparison of Dividend, Cash Flow, and Earnings Approaches to Equity Valuation." Contemporary Accounting Research 15, 343-383. 
Petersen, M. (2006). "Estimating Standard Errors in Finance Panel Data Sets: Comparing Approaches." Working paper, Northwestern University.

Shleifer, A. and R. Vishny. (1997). “A Survey of Corporate Governance.” Journal of Finance 52, 737-783.

Stulz, R. (1999). “Globalization, Corporate Finance, and the Cost of Capital.” Journal of Applied Corporate Finance 12, 8-25.

Subramanyam, K. (1996). "The Pricing of Discretionary Accruals." Journal of Accounting and Economics 22, 249-281.

Thompson, S. (2006). "Simple Formulas for Standard Errors that Cluster by Both Firm and Time." Working paper, Harvard University.

Watts, R. and J. Zimmerman. (1986). Positive Accounting Theory. Englewood Cliffs, NJ: Prentice-Hall. 
Table 1. Proportions of Firms with Cash Flow Forecasts Across Different Samples (by Country).

\begin{tabular}{|c|c|c|c|c|c|}
\hline Country & $\begin{array}{c}\text { Based on } \\
\text { DeFond and } \\
\text { Hung (2007) } \\
\text { (1) }\end{array}$ & $\begin{array}{l}\text { Based on Entire } \\
\text { Sample with } \\
\text { Available } \\
\text { Forecast Data } \\
\text { (2) }\end{array}$ & $\begin{array}{l}\text { Based on Entire } \\
\text { Sample with } \\
\text { Available } \\
\text { Accounting } \\
\text { Data } \\
\text { (3) }\end{array}$ & $\begin{array}{c}\text { Based on } 300 \\
\text { Largest Firms } \\
\text { by Country } \\
\text { (4) }\end{array}$ & $\begin{array}{c}\text { Based on } 100 \\
\text { Random Firms } \\
\text { by Country } \\
\text { (5) }\end{array}$ \\
\hline Argentina & $80 \%$ & $53 \%$ & $73 \%$ & $79 \%$ & $76 \%$ \\
\hline Australia & $95 \%$ & $84 \%$ & $96 \%$ & $100 \%$ & $97 \%$ \\
\hline Austria & $94 \%$ & $84 \%$ & $90 \%$ & $89 \%$ & $92 \%$ \\
\hline Belgium & $95 \%$ & $89 \%$ & $94 \%$ & $97 \%$ & $89 \%$ \\
\hline Brazil & $75 \%$ & $50 \%$ & $72 \%$ & $93 \%$ & $74 \%$ \\
\hline Canada & $75 \%$ & $68 \%$ & $79 \%$ & $82 \%$ & $86 \%$ \\
\hline Chile & $50 \%$ & $39 \%$ & $53 \%$ & $64 \%$ & $62 \%$ \\
\hline Colombia & $63 \%$ & $42 \%$ & $60 \%$ & $60 \%$ & $60 \%$ \\
\hline Denmark & $88 \%$ & $72 \%$ & $82 \%$ & $92 \%$ & $79 \%$ \\
\hline Finland & $83 \%$ & $74 \%$ & $80 \%$ & $95 \%$ & $82 \%$ \\
\hline France & $93 \%$ & $85 \%$ & $93 \%$ & $99 \%$ & $93 \%$ \\
\hline Germany & $75 \%$ & $69 \%$ & $79 \%$ & $97 \%$ & $77 \%$ \\
\hline Greece & $91 \%$ & $68 \%$ & $79 \%$ & $95 \%$ & $81 \%$ \\
\hline Hong Kong & $81 \%$ & $64 \%$ & $79 \%$ & $96 \%$ & $76 \%$ \\
\hline India & $90 \%$ & $84 \%$ & $94 \%$ & $94 \%$ & $92 \%$ \\
\hline Ireland & $85 \%$ & $72 \%$ & $83 \%$ & $85 \%$ & $83 \%$ \\
\hline Italy & $92 \%$ & $78 \%$ & $83 \%$ & $88 \%$ & $79 \%$ \\
\hline Japan & $14 \%$ & $23 \%$ & $25 \%$ & $35 \%$ & $16 \%$ \\
\hline Korea & $95 \%$ & $89 \%$ & $95 \%$ & $97 \%$ & $96 \%$ \\
\hline Malaysia & $71 \%$ & $65 \%$ & $77 \%$ & $91 \%$ & $70 \%$ \\
\hline Mexico & $93 \%$ & $68 \%$ & $93 \%$ & $97 \%$ & $94 \%$ \\
\hline The Netherlands & $95 \%$ & $87 \%$ & $97 \%$ & $99 \%$ & $94 \%$ \\
\hline New Zealand & $97 \%$ & $86 \%$ & $97 \%$ & $96 \%$ & $95 \%$ \\
\hline Norway & $95 \%$ & $79 \%$ & $85 \%$ & $94 \%$ & $86 \%$ \\
\hline Pakistan & $90 \%$ & $67 \%$ & $82 \%$ & $82 \%$ & $82 \%$ \\
\hline Philippines & $76 \%$ & $77 \%$ & $87 \%$ & $93 \%$ & $85 \%$ \\
\hline Portugal & $98 \%$ & $92 \%$ & $98 \%$ & $98 \%$ & $97 \%$ \\
\hline Singapore & $75 \%$ & $71 \%$ & $82 \%$ & $95 \%$ & $84 \%$ \\
\hline South Africa & $59 \%$ & $35 \%$ & $54 \%$ & $55 \%$ & $64 \%$ \\
\hline Spain & $93 \%$ & $89 \%$ & $95 \%$ & $99 \%$ & $90 \%$ \\
\hline Sweden & $88 \%$ & $73 \%$ & $80 \%$ & $96 \%$ & $78 \%$ \\
\hline Switzerland & $86 \%$ & $83 \%$ & $88 \%$ & $96 \%$ & $88 \%$ \\
\hline Thailand & $81 \%$ & $83 \%$ & $83 \%$ & $99 \%$ & $84 \%$ \\
\hline Turkey & $90 \%$ & $55 \%$ & $76 \%$ & $89 \%$ & $74 \%$ \\
\hline U.K. & $72 \%$ & $64 \%$ & $73 \%$ & $96 \%$ & $72 \%$ \\
\hline U.S. & $14 \%$ & $11 \%$ & $32 \%$ & $49 \%$ & $25 \%$ \\
\hline $\begin{array}{l}\text { Spearman's Rank } \\
\text { Correlation with (1) }\end{array}$ & & $0.830 * * *$ & $0.885 * * *$ & $0.639 * * *$ & $0.846^{* * *}$ \\
\hline
\end{tabular}

The table reports the proportions (in percent) of firms having one-year ahead analyst earnings forecasts and at least one cash flow forecast in the period from 1994 through 2002, by country. The columns represent the following samples: (1) the sample as reported in Table 1 of DeFond and Hung (2007); (2) all firms with one-year ahead earnings forecasts contained in the $\mathrm{I} / \mathrm{B} / \mathrm{E} / \mathrm{S}$ detail files; (3) all firms that in addition to the $\mathrm{I} / \mathrm{B} / \mathrm{E} / \mathrm{S}$ forecasts also have the necessary Worldscope financial data; (4) the 300 observations from each country with the largest US\$ market value of outstanding equity measured at the end of the fiscal year; and (5) 100 randomly selected observations by country with forecast and financial data available. The last row presents Spearman's rank correlation between column (1) and the remaining columns. ${ }^{* * *}$ indicates statistical significance at the $1 \%$ level. 
Table 2. Sensitivity Analyses of the Main Empirical Findings from DeFond and Hung (2007).

Dependent Variable ${ }_{i, t \text { or } ~}=\beta_{0}+\beta_{1} \mathrm{ANTIDIR}_{c}+\beta_{2} \mathrm{ENFOR}_{c}+\beta_{3} \mathrm{DISCLOSE}_{c}+\beta_{4} \mathrm{FRGINV}_{c}+\beta_{5} \mathrm{BIG}_{i}+\beta_{6} \mathrm{ANALYST}_{i, t}$

$+\beta_{7} \mathrm{SIZE}_{i, t}+\beta_{8} \mathrm{XLIST}_{i}+\sum \beta_{j}$ Industry Fixed Effects $_{i}+\sum \beta_{k}$ Year Fixed Effects $_{t}+\varepsilon_{i, t \text { or } c}$

Firm-Level Model

(Logit Regressions with Cash Flow Forecast Indicator as Dependent Variable)

\begin{tabular}{|c|c|c|c|c|c|}
\hline \multirow[b]{2}{*}{ Independent Variables } & & \\
\hline & $\begin{array}{c}\text { Model 1: } \\
\text { Standard Errors } \\
\text { Clustered by } \\
\text { Country/Industry } \\
\end{array}$ & $\begin{array}{c}\text { Model 2: } \\
\text { Standard Errors } \\
\text { Clustered by } \\
\text { Country }\end{array}$ & $\begin{array}{c}\text { Model 3: } \\
\text { Based on Entire Sample } \\
\text { with Available } \\
\text { Accounting Data }\end{array}$ & $\begin{array}{c}\text { Model 4: } \\
\text { Based on } 300 \text { Largest } \\
\text { Firms by Country }\end{array}$ & $\begin{array}{c}\text { Model 5: } \\
\text { Based on 100 } \\
\text { Random Firms by } \\
\text { Country } \\
\end{array}$ \\
\hline Intercept & $\begin{array}{l}-1.49 \\
(-1.33)\end{array}$ & $\begin{array}{l}-1.49 \\
(-0.56)\end{array}$ & $\begin{array}{c}2.22 \\
(1.20)\end{array}$ & $\begin{array}{c}1.35 \\
(0.72)\end{array}$ & $\begin{array}{c}1.18 \\
(0.68)\end{array}$ \\
\hline Investor Protection Var & & & & & \\
\hline ANTIDIR & $\begin{array}{l}-0.65 * * * \\
(-6.85)\end{array}$ & $\begin{array}{l}-0.65 * * * \\
(-2.76)\end{array}$ & $\begin{array}{l}-0.27^{*} \\
(-1.89)\end{array}$ & $\begin{array}{l}-0.40 * * \\
(-2.45)\end{array}$ & $\begin{array}{l}-0.25^{*} \\
(-1.75)\end{array}$ \\
\hline ENFOR & $\begin{array}{l}-0.42 * * * \\
(-4.87)\end{array}$ & $\begin{array}{l}-0.42 * * \\
(-2.05)\end{array}$ & $\begin{array}{c}0.02 \\
(0.14)\end{array}$ & $\begin{array}{c}0.03 \\
(0.26)\end{array}$ & $\begin{array}{c}0.05 \\
(0.38)\end{array}$ \\
\hline Control Variables: & & & & & \\
\hline DISCLOSE & $\begin{array}{l}0.09 * * * \\
(5.15)\end{array}$ & $\begin{array}{l}0.09^{* *} \\
(2.14)\end{array}$ & $\begin{array}{c}0.00 \\
(0.04)\end{array}$ & $\begin{array}{c}0.03 \\
(0.89)\end{array}$ & $\begin{array}{c}0.01 \\
(0.39)\end{array}$ \\
\hline FRGINV & $\begin{array}{l}0.13 * * * \\
(4.94)\end{array}$ & $\begin{array}{l}0.13^{* *} \\
(2.09)\end{array}$ & $\begin{array}{c}0.02 \\
(0.66)\end{array}$ & $\begin{array}{c}0.02 \\
(0.41)\end{array}$ & $\begin{array}{l}-0.01 \\
(-0.23)\end{array}$ \\
\hline BIG5 & $\begin{array}{l}-0.38 * * * \\
(-2.98)\end{array}$ & $\begin{array}{c}-0.38 \\
(-1.39)\end{array}$ & & & \\
\hline ANALYST & $\begin{array}{l}0.13^{* * *} \\
(6.06)\end{array}$ & $\begin{array}{l}0.13^{* *} \\
(2.49)\end{array}$ & & & \\
\hline SIZE & $\begin{array}{l}-0.13 * * * \\
(-2.73)\end{array}$ & $\begin{array}{c}-0.13 \\
(-1.29)\end{array}$ & & & \\
\hline XLIST & $\begin{array}{l}-0.46^{* * *} \\
(-4.15)\end{array}$ & $\begin{array}{l}-0.46^{* *} \\
(-2.34)\end{array}$ & & & \\
\hline $\begin{array}{l}\text { Industry and Year } \\
\text { Fixed Effects }\end{array}$ & Yes & Yes & & & \\
\hline $\begin{array}{l}\text { (Pseudo) } \mathrm{R}^{2} \\
\text { \# Observations }\end{array}$ & $\begin{array}{r}27.66 \% \\
51,663\end{array}$ & $\begin{array}{r}27.66 \% \\
51,663\end{array}$ & $\begin{array}{r}12.62 \% \\
36\end{array}$ & $\begin{array}{c}16.29 \% \\
36\end{array}$ & $\begin{array}{l}8.62 \% \\
36\end{array}$ \\
\hline
\end{tabular}

Country-Level Model

OLS Regressions with Proportion of Cash Flow Forecasts as Dependent Variable) 
The sample comprises a maximum of 51,663 firm-year observations from 36 countries from 1994 through 2002, for which sufficient I/B/E/S one-year ahead analyst forecasts, Worldscope financial data, and legal institutional data exist. I estimate the country-level regressions based on the following samples: all firms that in addition to I/B/E/S forecasts also have the necessary Worldscope financial data (Model 3); the 300 observations from each country with the largest US\$ market value of outstanding equity measured at the end of the year (Model 4); and 100 randomly selected observations by country with forecast and financial data available (Model 5). In the Logit regressions, I use a binary indicator as the dependent variable that equals one if the firm has both earnings and cash flow forecasts and zero if it only has earnings forecasts. In the OLS regressions the dependent variable equals the $\log \operatorname{transformed}-\mathrm{i}$.e., $\ln (x /(1-x))$ where $x$ is the raw value - proportion of firms having both analyst earnings and cash flow forecasts by country. The investor protection variables consist of two measures from La Porta et al. (1998): the antidirector rights index (ANTIDIR) capturing the legal protection of minority shareholders and the quality of the legal enforcement (ENFOR) measured by the mean of three institutional variables (i.e., efficiency of the judicial system, rule of law, and corruption index). DISCLOSE represents a country's disclosure practice using the country means of the 1995 CIFAR firm-level disclosure scores. FRGINV measures the average foreign investments in an economy, scaled by GDP (see DeFond and Hung, 2007, Table 2). BIG5 is a binary indicator taking on the value of one if the company has a Big Five audit firm. ANALYST indicates the number of analysts issuing forecasts for the firm in a given year. SIZE is the natural $\log$ of the market value of outstanding equity (in US\$ thousands) at the end of the year. XLIST is a binary indicator taking on the value of one if the company's shares are listed on multiple international stock exchanges. $\mathrm{I} / \mathrm{B} / \mathrm{E} / \mathrm{S}$ industry and year indicators are included in the firm-level regressions but not reported. The table reports coefficient estimates and, in parentheses, z-statistics (t-statistics) based on heteroscedasticity-corrected standard errors that are clustered by country and industry (Model 1) or country (Model 2 ). ${ }^{* * *},{ }^{* *}$, and $*$ indicate statistical significance at the $1 \%, 5 \%$, and $10 \%$ levels (two-tailed), respectively. 
Table 3. Univariate Analysis of the Cash Flow Forecast Propensity Surrounding Changes in Investor Protection and/or Earnings Quality.

Proportion of Firms with Cash Flow Forecasts (in Percent) and Number of Observations

\begin{tabular}{|c|c|c|c|c|}
\hline \multicolumn{5}{|c|}{ Panel A: First Enforcement of Insider Trading Laws } \\
\hline & & $\begin{array}{l}\text { Pre-Period } \\
\text { (1) }\end{array}$ & $\begin{array}{l}\text { Post-Period } \\
\text { (2) }\end{array}$ & $\begin{array}{l}\text { Difference } \\
(2)-(1)\end{array}$ \\
\hline \multirow[t]{5}{*}{ ANTIDIR } & Low $(<4)$ & $37.33 \%$ & $74.54 \%$ & $37.21 * * *$ \\
\hline & (a) & 434 & 2,922 & \multirow{4}{*}{$20.06^{* * *}$} \\
\hline & $\operatorname{High}(\geq 4)$ & $57.80 \%$ & $77.86 \%$ & \\
\hline & (b) & 635 & 2,105 & \\
\hline & $\begin{array}{l}\text { Difference } \\
\text { (a) - (b) }\end{array}$ & $-20.47 * * *$ & $-3.32 * * *$ & \\
\hline
\end{tabular}

Panel B: U.S. Exchange Listing (Level II or III)

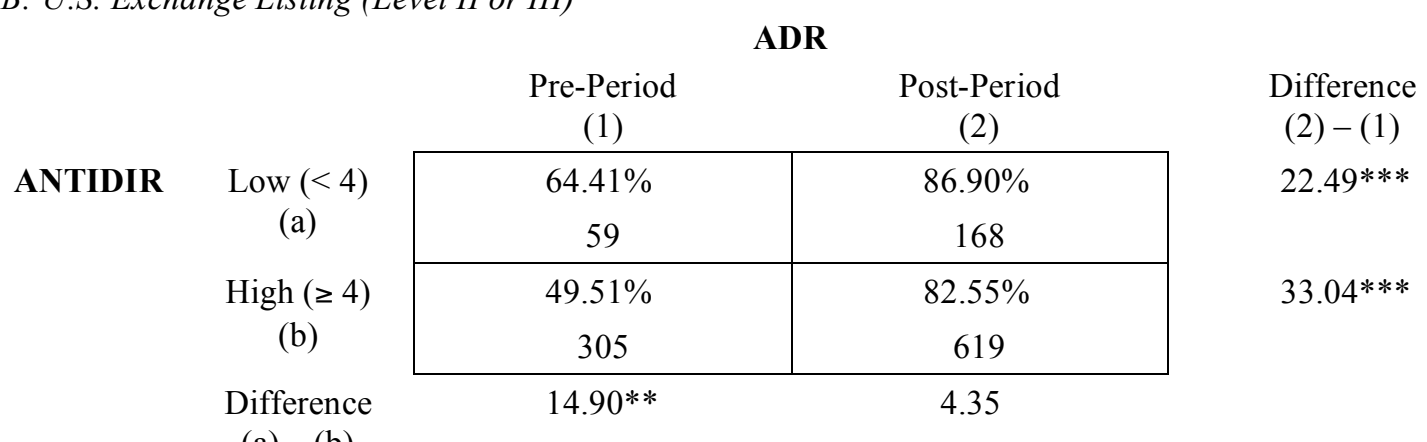

Panel C: Voluntary IFRS or U.S. GAAP Adoption

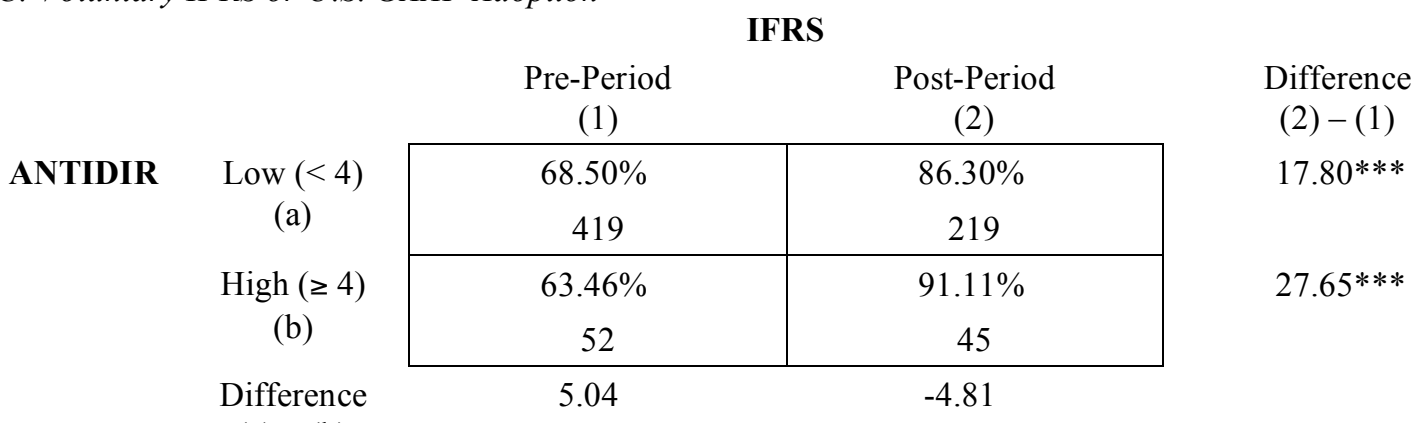

The respective samples comprise all firm-year observations from 1994 through 2004 for which sufficient I/B/E/S one-year ahead analyst forecasts and Worldscope financial data exist and include only firms with at least one observation in either the period before and after the change in investor protection (earnings quality). I partition the time-series of observations based on three binary indicators: (1) INSIDETR takes on the value of one beginning in the year of the first prosecution under insider trading laws in national stock markets (Bhattacharya and Daouk, 2002); (2) ADR is set equal to one beginning in the year of a non-U.S. firm's exchange listing on the NYSE, NASDAQ or AMEX (see Hail and Leuz, 2006b); and (3) IFRS is set equal to one beginning in the year of a firm's voluntary adoption of IFRS or U.S. GAAP instead of (or in addition to) its domestic accounting standards. I further split the samples into low and high investor protection countries according to the median value of the antidirector rights index (ANTIDIR) from La Porta et al. (1998). The table reports the proportions (in percent) of firms having analyst earnings and cash flow forecasts as well as the number of observations in each cell. $* * *$ and ** indicate statistical significance at the $1 \%$ and $5 \%$ levels (two-tailed), respectively, based on a t-test. 
Table 4. Logit Panel Regression Analysis of the Cash Flow Forecast Propensity Surrounding Changes in Investor Protection and/or Earnings Quality.

Cash Flow Forecast Indicator ${ }_{i, t}=\alpha_{1}$ Post-Change in Investor Protection/Earnings Quality Indicator $_{i, t}+\alpha_{2} \mathrm{ANALYST}_{i, t}+\alpha_{3} \mathrm{SIZE}_{i, t}$ $+\alpha_{4} \mathrm{LEV}_{i, t}+\alpha_{5}$ FRGSALES $_{i, t}+\alpha_{6}$ ROE $_{i, t}+\sum \alpha_{j}$ Firm Fixed Effects $_{i}+\sum \alpha_{k}$ Year Fixed Effects $_{t}+v_{i, t}$

\begin{tabular}{|c|c|c|c|c|c|c|c|c|c|}
\hline \multirow[b]{2}{*}{ Independent Variables } & \multicolumn{3}{|c|}{$\begin{array}{l}\text { First Enforcement of } \\
\text { Insider Trading Laws }\end{array}$} & \multicolumn{3}{|c|}{$\begin{array}{l}\text { U.S. Exchange Listing } \\
\text { (Level II or III) }\end{array}$} & \multicolumn{3}{|c|}{$\begin{array}{l}\text { Voluntary IFRS or } \\
\text { U.S. GAAP Adoption }\end{array}$} \\
\hline & Model 1 & Model 2 & Model 3 & Model 1 & Model 2 & Model 3 & Model 1 & Model 2 & Model 3 \\
\hline \multicolumn{10}{|c|}{ Post-Change Indicator Variables: } \\
\hline INSIDETR & $\begin{array}{l}2.10 * * * \\
(19.93)\end{array}$ & $\begin{array}{l}0.64 * * * \\
(3.15)\end{array}$ & $\begin{array}{l}0.49 * * \\
(2.32)\end{array}$ & & & & & & \\
\hline ADR & & & & $\begin{array}{l}3.37 * * * \\
(9.21)\end{array}$ & $\begin{array}{l}1.02 * * \\
(2.41)\end{array}$ & $\begin{array}{l}0.94 * * \\
(2.03)\end{array}$ & & & \\
\hline IFRS & & & & & & & $\begin{array}{l}1.87 * * * \\
(5.82)\end{array}$ & $\begin{array}{l}1.04 * * \\
(2.36)\end{array}$ & $\begin{array}{l}1.18 * * \\
(2.44)\end{array}$ \\
\hline \multicolumn{10}{|l|}{ Control Variables: } \\
\hline ANALYST & $\begin{array}{l}0.27 * * * \\
(19.91)\end{array}$ & $\begin{array}{l}0.34 * * * \\
(20.58)\end{array}$ & $\begin{array}{l}0.34 * * * \\
(18.01)\end{array}$ & $\begin{array}{l}0.23 * * * \\
(7.44)\end{array}$ & $\begin{array}{l}0.23 * * * \\
(6.60)\end{array}$ & $\begin{array}{l}0.25 * * * \\
(5.88)\end{array}$ & $\begin{array}{l}0.31 * * * \\
(7.14)\end{array}$ & $\begin{array}{l}0.27 * * * \\
(5.90)\end{array}$ & $\begin{array}{l}0.29 * * * \\
(5.39)\end{array}$ \\
\hline SIZE & $\begin{array}{l}0.28 * * * \\
(4.98)\end{array}$ & $\begin{array}{l}0.24 * * * \\
(3.74)\end{array}$ & $\begin{array}{l}0.42 * * * \\
(4.56)\end{array}$ & $\begin{array}{l}0.54 * * * \\
(3.55)\end{array}$ & $\begin{array}{l}0.33^{*} \\
(1.70)\end{array}$ & $\begin{array}{c}0.26 \\
(1.12)\end{array}$ & $\begin{array}{c}0.20 \\
(1.11)\end{array}$ & $\begin{array}{l}0.15 \\
(0.66)\end{array}$ & $\begin{array}{c}0.43 \\
(1.32)\end{array}$ \\
\hline LEV & & & $\begin{array}{l}0.08 * * * \\
(3.61)\end{array}$ & & & $\begin{array}{c}0.02 \\
(0.24)\end{array}$ & & & $\begin{array}{l}0.19^{* * * *} \\
(2.67)\end{array}$ \\
\hline FRGSALES & & & $\begin{array}{l}0.74 * * \\
(2.10)\end{array}$ & & & $\begin{array}{l}-0.42 \\
(-0.58)\end{array}$ & & & $\begin{array}{c}-0.08 \\
(-0.06)\end{array}$ \\
\hline ROE & & & $\begin{array}{c}-0.44 \\
(-1.61)\end{array}$ & & & $\begin{array}{c}0.37 \\
(0.56)\end{array}$ & & & $\begin{array}{c}-0.07 \\
(-0.10)\end{array}$ \\
\hline Firm Fixed Effects & Yes & Yes & Yes & Yes & Yes & Yes & Yes & Yes & Yes \\
\hline Year Fixed Effects & & Yes & Yes & & Yes & Yes & & Yes & Yes \\
\hline \# Observations & 6,096 & 6,096 & 4,922 & 1,151 & 1,151 & 933 & 735 & 735 & 618 \\
\hline \# Firms & 921 & 921 & 767 & 137 & 137 & 118 & 101 & 101 & 87 \\
\hline \# Countries & 12 & 12 & 12 & 19 & 19 & 16 & 9 & 9 & 8 \\
\hline
\end{tabular}

The respective samples comprise all firm-year observations from 1994 through 2004 for which sufficient I/B/E/S one-year ahead analyst forecasts and Worldscope financial data exist and include only firms with at least one observation in either the period before and after the change in investor protection (earnings quality). The dependent variable is a binary indicator that equals one if the firm has both earnings and cash flow forecasts and zero if it only has earnings forecasts. I partition the time-series of observations based on three binary indicators: (1) INSIDETR takes on the value of one beginning in the year of the first prosecution under insider trading laws in national stock markets (Bhattacharya and Daouk, 2002); (2) ADR is set equal to one beginning in the year of a non-U.S. firm's exchange listing on the NYSE, NASDAQ or AMEX (see Hail and Leuz, 2006b); and (3) IFRS is set equal to one beginning in the year of a firm's voluntary adoption of IFRS or U.S. GAAP instead of (or in addition to) its domestic accounting standards. ANALYST indicates the number of analysts issuing forecasts for the firm in a given year. SIZE is the natural log of the market value of outstanding equity (in US\$ thousands). LEV is the ratio of total liabilities to market value of outstanding equity. FRGSALES represents a firm's foreign sales as percentage of total sales. Accounting return on equity, ROE, is earnings per share divided by beginning of period book value per share. Financial data are measured as of the fiscal-year end. Firm and year fixed effects are included in the regressions, where indicated, but not reported. The table reports coefficient estimates and, in parentheses, z-statistics based on heteroscedasticitycorrected standard errors. $* * *, * *$, and $*$ indicate statistical significance at the $1 \%, 5 \%$, and $10 \%$ levels (two-tailed), respectively. 